\title{
OPEN REGIONALISM IN A WORLD OF CONTINENTAL TRADE BLOCS
}

Shang-Jin Wei

Jeffrey A. Frankel

Working Paper 5272

\section{NATIONAL BUREAU OF ECONOMIC RESEARCH 1050 Massachusetts Avenue \\ Cambridge, MA 02138 \\ September 1995}

We would like to thank Jungshik Kim for efficient research assistance and Greg Dorchak for excellent editorial assistance. All errors are our responsibility. This paper is part of NBER's research program in International Trade and Investment. Any opinions expressed are those of the authors and not those of the National Bureau of Economic Research.

() 1995 by Shang-Jin Wei and Jeffrey A. Frankel. All rights reserved. Short sections of text, not to exceed two paragraphs, may be quoted without explicit permission provided that full credit, including $\odot$ notice, is given to the source. 


\title{
OPEN REGIONALISM IN A WORLD
}

OF CONTINENTAL TRADE BLOCS

\begin{abstract}
Continental trade blocs are emerging in many parts of the world almost in tandem. If trade blocs are required to satisfy the McMillan criterion of not lowering their trade volume with outside countries, they have to engage in a dramatic reduction of trade barriers against nonmember countries. That may not be politically feasible. On the other hand, in a world of simultaneous continental trade blocs, an open regionalism in which trade blocs undertake relatively modest external liberalization can usually produce Pareto improvement. In the bilateral trade data for the period 1970-92, there are indeed regions that, while exhibiting an inward trade bias, nevertheless are consistent with this notion of open regionalism.
\end{abstract}

Shang-Jin Wei

Kennedy School of Government

Harvard University

79 JFK Street

Cambridge, MA 02138

and NBER
Jeffrey A. Frankel

Department of Economics

Evans Hall

University of California

Berkeley, CA 94720

and NBER 


\section{Introduction}

Parallel to a proliferation of regional trade agreements, there is a renewed debate about their welfare implications. Recent studies (e.g., Krugman 1991a; Bhagwati, 1993; and Frankel, Stein and Wei, 1994) provide intellectual support for the worry that the current pattern of regionalization is likely to be welfare-reducing.

There are two important features of the current wave of regionalization. First, some initiatives are proposed along continental lines. Second, regional arrangements are put forward or accelerated in various parts of the world simultaneously. For example, in the Western Hemisphere, after the conclusion of the NAFTA, the United States in 1994 proposed to discuss a possible bloc that will cover most of the countries in the Americas. In Western Europe, the European Union and the European Free Trade Area (EFTA) in 1992 established the European Economic Area, thus formalizing their already highly integrated economic relation. In Asia, where explicit trade blocs are relatively lacking, there is an alleged Japan-centered implicit trade bloc and an explicit proposal on the table to form an East Asia Economic Caucus. A recently upgraded APEC that encompasses most of the East Asian countries, North America, Australia and New Zealand, has declared its intention to achieve free trade. These features of the recent regionalization pattern have caught the attention of academics. Krugman (1991a) and Summers (1991), for example, noted that continental trade blocs are more likely to be welfare-improving than otherwise.

In somewhat different contexts, two concepts have been proposed with the aim to mitigate the negative side of trade blocs. The first is "open regionalism," and the second is the Kemp- 
Wan-McMillan Criterion. We have two objectives in this paper. First, we seek to understand the usefulness of these concepts as a guide to minimizing the possibility of welfare-reducing trade blocs, while facilitating welfare-improving ones. We pay particular attention to issues related to a world of simultaneously formed continental trade blocs. Second, we examine empirically the extent to which the existing pattern of regionalization is consistent with a Paretoimproving "open regionalism."

"Open regionalism" is a catchy concept, because it supposedly promotes certain types of regional blocs that entail little trade diversion. A more careful examination of its validity is hampered by a lack of a uniform definition of the phrase. Some economists simply dismiss it as an oxymoron.

Along a more theoretical dimension, Kemp and Wan (1976) showed that trade blocs can always be constructed in a way that represents a Pareto improvement. McMillan (1993) proposes changing GATT XXIV to require that there be no decrease in trade volume between member and non-member countries after the formation of a bloc. This essentially calls for a reduction of trade barriers by member countries against non-members. The criterion is devised in the context of formation of a single bloc, as opposed to several continental blocs. We will argue that in a world where several continental blocs are emerging at the same time, this criterion may be unnecessarily strong. A more modest criterion can in fact ensure welfare improvement.

We organize the paper in the following way. Section 2 provides a brief overview of the evolution of thought on continental blocs. In the process, we also seek to clarify the meaning of the phrase, "open regionalism." Section 3 employs a simple model to investigate conditions 
needed to ensure Pareto-improvement of continental trade blocs. To be sure, the model is of a static differentiated product type, thus sharing many of same advantages and disadvantages of this type of model. In Section 4, using data on over 1,500 country pairs during 1970-92, we examine the likelihood that the current continental blocs conform to "open regionalism." Section 5 provides some concluding remarks.

\section{General discussion}

There are several stages in the intellectual discussion of desirability of regional trade blocs. The classical dichotomy between trade creation and diversion as advanced by Viner (1950) Meade (1955) and its many modifications have dominated people's thinking for many decades. It is clearly recognized that regional trade blocs can be welfare-reducing. The actual welfare implication of a particular pattern of regionalization, it was thought, has to be determined on a case-by-case basis.

At the beginning of the 1990 s, along with a renewed interest in regional blocs in the policy world, a potent warning about the possibility of welfare deterioration was emitted by a simple and elegant paper by Krugman (1991a). Using a model of trading blocs based on preference for variety and increasing returns to scale, the author demonstrated through simulation that three blocs may be the worst scenario, in a world with symmetric countries and no transport cost. Given the suspicion that the world is indeed moving towards a three-bloc pattern, this theoretical result seemed particularly alarming.

To counterbalance the fear, Krugman (1991b) soon supplied an equally ingenious if 
somewhat extreme example in which three continental blocs may be welfare-improving if the inter-continental transport cost is very high. The intuition is simple: if the transportation costs are prohibitively high across continents, then world trade would take place primarily between countries on the same continent even under global free trade. Therefore, a world net of continental free trade blocs must be welfare improving since this is basically the best one can achieve in any case. For this reason, continental trade blocs are referred to as "natural trade blocs" by Krugman, in contrast to "unnatural trade blocs," free trade agreements between countries that are far away.

Of course, the real world is somewhere between zero transport cost (as in the first Krugman paper) and an infinite transport cost (as in the second). Does the welfare implication of continental blocs depend monotonically on intercontinental transport cost? If so, is the level of transport costs in the real world above or below the threshold?

Stein and Frankel (1993) showed that the answer to the first question is yes: there is a threshold value of intercontinental transport cost, above which, continental blocs are likely to be welfare-improving; and below which, the reverse is true. Carrying the argument one step further, Frankel, Stein and Wei (1994) showed that the best estimate of the intercontinental transport cost (about $15 \%$ of the trade) is below the threshold. Hence, the current pattern of regionalization is likely to be excessive and welfare-reducing. They call this type of continental blocs that are nevertheless welfare-reducing "supernatural blocs."

It has been noted that, if one allows neighboring countries to have complementary resource endowments that are nearly complete for the countries as a group, then a system of regional blocs among neighbors can also be welfare-improving (Deardorff and Stern, 1992). 
This is a point well-understood by now. On the other hand, it is a strong assumption to make that resource endowments of neighboring countries are so nearly complete that they do not need to trade with outside countries ${ }^{1}$. In any case, factor-endowment-based models do not seem to fit the bilateral trade volume data as well as a gravity model that ignores endowment.

We should note that the above discussion centers around the static efficiency gains or losses. The dynamic gains (or losses) are often more important (Baldwin, 1991). Finally, while this paper concentrates on economic efficiency, political economy of trade blocs is also an important issue. There is a debate about whether regional blocs have acted as stepping stones or stumbling blocks to global free trade (Bhagwati, 1993; Lawrence, 1992; Levy, 1993; Wei and Frankel, 1994). The issue is not resolved yet.

The concept of "open regionalism" was formally introduced during the APEC discussion. It is thought to entail a structure that minimizes trade diversion. At first, the term appears as an oxymoron. Regionalism is a departure from the Most-Favored-Nation principle as it discriminates in favor of members at the expense of non-members. How can it be open at the same time?

To clarify, let us entertain four possible definitions of "open regionalism." (1) Open membership. Entry rules are transparent so that any currently outside country can choose to join the bloc as long as it satisfies the entry criteria. (2) Non-prohibition clause A regional trade agreement can automatically allow any member country to liberalize unilaterally, in particular, to extend the benefits of a regional agreement to non-member countries. (3) Selective

1 Haveman (1992) derives a model that marries endowment consideration with differentiated product consideration. He found in his simulation that the negative effects of regional trade blocs are likely to dominate. 
liberalization and open benefits Member countries can focus on liberalizing, on an MFN basis, those sectors where they dominate world trade so that they do not need to have preferential treatment against non-member countries. (4) Reduction in external barriers Members of a regional trade bloc should collectively lower their external barriers on goods from non-member countries $^{2}$. The degree of liberalization against non-members need not be as high as that among members.

Wei and Frankel (1995) argue that the first three definitions are virtuous but powerless. The first two are desirable characteristics of any trade bloc but are likely to be part of them anyway. Most importantly, neither of them actually eliminates welfare-reducing trade blocs. The third definitionis is virtuous but a bit vacuous as it calls for a departure from the basic nature of trade blocs.

The last definition is the best one, as it potentially offers a criterion for regional blocs to be welfare-improving. It is closely related to the Kemp and Wan (1976) theorem and the McMillan proposal (1993) as both require member countries to undertake liberalization against non-members. Indeed, the McMillan proposal is a particular kind of open regionalism in which the degree of external liberalization is such that trade between member countries and nonmembers are the same as before the formation of blocs. The question is, whether it is necessary for trade blocs to obey the McMillan rule in order to be welfare-improving? To get a clearer answer, we turn to a simple model.

\footnotetext{
2 We do not distinguish between customs unions (CUs) and free trade areas (FTAs). Krueger (1995) has argued that CUs are (almost) always welfare-superior to FTAs. Moreover, in terms of political economy, cUs are also less likely to be stumbling blocks to further global trade liberalization than FTAs.
} 


\section{An illustrative model}

The simple model owes its basic structure to Krugman (1980 and 1991), but is most directly based on Stein and Frankel (1994) and Frankel, Stein and Wei (1994), which incorporate transport costs into the Krugman model. For the purpose of examining "open regionalism" and the McMillan proposal, we allow for an explicit consideration of extra-bloc liberalization.

For several reasons, we will restrict our attention to continental trade blocs, i.e., trade blocs formed among countries on the same continent. First, some empirical evidence suggests the existence of intra-continental trade bias in Western Europe, Western Hemisphere and East Asia. Furthermore, in Pacific Asia, once we control for the whole East Asia effect, subregions such as ASEAN no longer exhibit additional inward bias. Second, some influential authors claim that continental blocs are "natural" groupings and likely to be welfare improving since the extent of trade diversion may be smaller than for other kinds of arrangement (Summers, 1991; Krugman, 1991b; see also Bhagwatti, 1993 for a dissenting view). Third, this also follows closely the paper by Frankel-Stein-Wei(1994), which examines the likelihood of a welfarereducing continental trade blocs (dubbed "super-natural blocs"). The main interest of this paper is to uncover the minimum degree of open regionalism at which continental trade blocs can be welfare-improving. 


\subsection{Basic model}

\section{Stylized "World Geography"}

We consider a symmetric world in which all countries are linked through a hub and spoke transport system. There are altogether $\mathrm{C}$ continents with $\mathrm{N}$ countries on each one.

On any continent, all countries (spokes) are of the same distance from the center of the continent (hub). Transportation of any good from one country to another must go through the hub. Transportation cost is modelled by an "iceberg" assumption: $\alpha$ percent of the good melts on the way. In other words, only $1-\alpha$ unit of goods arrived in the importing country for every unit of goods exported.

To ship a good between countries on different continents, one has to travel from the exporting country to its continent's hub, then to the hub of importing continent, before reaching the importing country. With the same "iceberg" assumption, for every unit of good exported, approximately $(1-\alpha)(1-b)$ unit arrives in the importing country. " $\alpha$ " and "b" can be interpreted as intra- and inter-continental transport costs, respectively.

Without loss of generality, we assume that each country produces one good.

\section{Consumer's problem}

A representative consumer solves the following utility maximization problem:

where $0<\theta<1$ is a parameter representing the degree of substitutability. 
$\max \sum_{1} c_{1}^{\theta}$

Her budget constraint is

$$
P_{h} C_{h}+\sum_{j} P_{c, y} C_{c, j}+\sum_{m} P_{n c, m} C_{n c, m}=w+T
$$

where $C_{h}, C_{c, j}$, and $C_{n c, n 1}$ are consumption goods produced, respectively, in the home country, foreign country $\mathrm{j}$ on the same continent, and foreign country $\mathrm{m}$ on a different continent. P's are prices of those goods from the corresponding source countries. $w$ is her endowment. $T$ is the home country's total tariff revenue, distributed to the consumer in a lump-sum fashion.

The consumer takes the prices and tariff level as given in solving her problem. Without loss of generality, we can normalize $w$ and $P_{h}$ to be one. Simple manipulation of the first order conditions yields that $C_{c, y}=C_{b}\left(P_{c, y}\right)^{\frac{1}{\theta-1}}$

and

$$
C_{n c, y}=C_{b}\left(P_{n c, y}\right)^{\frac{1}{\theta-1}}
$$

Before we complete the consumer's problem, it is useful to consider the producer's and government's problems.

\section{Producer's problem}

Every producer is a monopolistic competitor. The production of any variety involves a fixed cost and constant marginal cost. As is shown in Krugman (1991a), every producer would choose to specialize in producing a different variety from other producers. 


\section{Government's problem}

Following Krugman (1991b) and Stein and Frankel (1994), we abstract from modelling the process through which governments choose their tariff level. Instead, we assume that, before the formation of any regional trade blocs, a uniform tariff rate is imposed on all imports. We do not let the governments impose optimal tariffs for three reasons. First, real world tariffs (or any trade barriers) are rarely erected for optimal tariff reasons. Second, as Krugman (1991a) shows, optimal tariffs in such models are much too high relative to the actual levels of barriers we observe. Third, although optimal tariffs tend to rise as countries form regional trade blocs, GATT specifically forbids countries from raising tariffs subsequent to the establishment of a regional bloc.

Denote by $t$ the initial level of tariff. Once a regional bloc is formed, within-bloc tariffs could be reduced to zero, while the extra-bloc tariffs may be kept as before. Instead of assuming this, we use somewhat more flexible expressions that allow for partial within-bloc and extra-bloc liberalization.

As assumed before, the price of home-country good is normalized to be one. The price of the goods from other countries on the same continent is

$$
P_{c}=\frac{1+(1-k) t}{1-a}
$$

where $\mathrm{k}$ indicates the extent of intra-bloc liberalization. For example, if $\mathrm{k}=1$, then the internal tariff is reduced to zero after the formation of the bloc. If $k=0.5$, the trade barriers are reduced only halfway by the regional bloc.

The price of goods from countries on different continents is 


$$
P_{n c}=\frac{1+(1-k 1) t}{(1-a)(1-b)}
$$

where 1 is the degree of extra-bloc liberalization. For example, if $1=0.5$, then the member countries of the bloc liberalize their trade against non-member countries half as much as they do with each other. That is, if the pre-bloc tariff level is $30 \%, k=1$ and $l=0.5$, then, with the formation of the bloc, member countries reduce their internal tariffs to zero and cut the tariff against countries outside the bloc to $15 \%$.

\section{Equilibrium}

In equilibrium, all countries are again symmetric, each producing the same amount. So a representative consumer in a representative home country imports the same amount from all other countries on the same continent:

$$
c_{c, y}=c_{c} \quad \text { for all } j
$$

She also imports the same amount from all countries on different continents:

$$
C_{n c, m}=C_{n c} \quad \text { for all } m
$$

The total tariff revenue a representative country collects in this symmetric world is

$$
T=(N-1) C_{c} \frac{(1-k) t}{1-a}+(C-1) N C_{n c} \frac{(1-k 1) t}{(1-a)(1-b)}
$$

Incorporating this into a representative consumer's budget constraint and making use of her first order conditions, we can solve for her consumption of the home variety: 


$$
C_{h}=\frac{w}{1+(N-1) \frac{P_{c}^{\frac{1}{\theta-1}}}{1-a}+(C-1) N \frac{P_{n c}^{\frac{1}{\theta-1}}}{(1-a)(1-b)}}
$$

Her consumption of imported varieties can be computed by using her first order conditions. Since all individuals in this world are identical, the world welfare is proportional to the utility level of the representative consumer. This can be worked out as

$$
\begin{gathered}
U=C_{h}^{\theta}+(N-1) C_{c}^{\theta}+(C-1) N C_{n c}^{\theta} \\
=C_{h}^{\theta}\left[1+(N-1) P_{c}^{\frac{\theta}{\theta-1}}+(C-1) N P_{n c}^{\frac{\theta}{\theta-1}}\right]
\end{gathered}
$$

\section{Trade volumes}

Imports from a member country of the same bloc

$$
V_{c}=C_{c}=C_{h} P_{c}^{\frac{1}{\theta-1}}
$$

Imports from a non-member country (i.e., on a different continent)

$$
V_{n c}=C_{n c}=C_{h} P_{n c}^{\frac{1}{\theta-1}}
$$




\subsection{Replication of earlier results}

To review the some of the basic results in Krugman (1991a) and Frankel, Stein and Wei (1994), and to check that the model does in fact encompass the earlier models as special cases, we replicate two key graphs here.

\section{Replication of Krugman's results}

The Krugman model (1991a) abstracts away transportation costs of all kinds, but has a structure otherwise similar to our model. If we set the intra- and inter-continental transport costs at zero in our model, and restrict the within-bloc and external liberalization to be $100 \%$ and zero percent, respectively, our model matches the Krugman case.

For illustration, we choose a world of 60 countries. We can divide the world evenly into one bloc (i.e., global free trade), two blocs, three blocs, and so on. For each division, we can compute the percentage change in world welfare relative to the case in which every country imposes a uniform tariff on imports from every other country (i.e., on a MFN basis). Following Krugman, we fix $\theta=0.75$ and tariff rate $=30 \%$. The result is graphed in Appendix Figure 1 .

In this as well as in the original Krugman graphs, we observe that, starting from the case of no blocs, as the world is increasingly regionalized (from twenty blocs to ten blocs to four blocs, etc.), world welfare decreases. However, world welfare is minimized at three blocs. After that, welfare rises again, and is maximized at global free trade (one grand bloc). 


\section{Replication of Frankel-Stein-Wei result}

Frankel, Stein and Wei (1994) pay particular attention to the connection between the size of inter-continental transaction costs and the welfare effects of regional bloc formation. The key graph assumes a world of three continents with two countries on each, all linked through a spike and hub system.

Appendix Figure 2 plots percentage change in welfare from three continental blocs (relative to a no-bloc status quo) against the size of inter-continental transport cost, b. As in their original plot, the welfare effect does indeed depends monotonically on $b$. When intercontinental transport cost is low, three blocs present lower welfare for the world than no blocs. On the other hand, when it is sufficiently costly to ship goods between continents, three blocs result in higher welfare than the no-bloc status quo. The critical value of inter-continental transport cost, $\mathrm{b}$, is about $18 \%$. If $\mathrm{b}$ is above the critical value, three continental blocs are "natural" in the sense of being welfare-improving; If intra-continental cost accounts for less than $18 \%$ of the trade value, three continental blocs are "super-natural" as they tend to reduce world welfare.

\subsection{Open regionalism}

Both in Krugman (1991a and b) and Frankel, Stein and Wei (1994), whenever countries form a regional bloc, they maintain (or even increase) their trade barriers against the countries outside the bloc. To examine the implications of the Kemp-Wan-McMillan proposal and "open regionalism," we now consider external liberalization. We abstract away from the mechanisms 
under which this takes place. But that presumably is the result of the balance of political economy forces.

\section{Benchmark}

In our benchmark case, we match the parameter values, whenever possible, to those in Frankel, Stein and Wei (1994). In particular, we consider a world of three equal distanced continents $(C=3)$ with two countries on each $(N=2)$. Before the formation of regional blocs, every country imposes a $30 \%$ tariff on imports from every other country on an MFN basis. The substitutability parameter in the Dixit-Stiglitz utility function, $\theta$, is set at 0.75 . The intercontinental transaction cost, b, is estimated at $15 \%$ in Frankel, Stein and Wei (1994). Hence, we set $b=0.15$. For simplicity, we set $a=0$. We will later examine sensitivity of our central results to different parameter values.

We compare trade volume (between members and non-members) and world welfare before and after the formation of continental trade blocs. Figure 1 plots the percentage changes of the two measures as a function of the degree of external liberalization, 1.

Three features are noteworthy. First, as the degree of external liberalization increases, both world welfare and trade volume with non-members rise monotonically. Second, the KempWan-McMillan proposal of not reducing external trade volume by member countries is equivalent to require a relatively large degree of trade liberalization. In this stylized model, member countries of the blocs have to reduce their external barriers by $40 \%$. Lastly and in contrast to the McMillan proposal, the degree of external liberalization required to ensure Pareto-improvement is less than $4 \%$. 
The Kemp-Wan-McMillan criterion is a sufficient condition for Pareto improvement, as the authors originally remarked. In many countries and regions, the required $40 \%$ external liberalization may be considered too large, and thus unlikely to be implemented by the domestic political process. The good news is that, in a world of simultaneous continental trade blocs, this large degree of external liberalization is overkill from the welfare point of view. In fact, an "open regionalism" with a modest $4 \%$ external liberalization can already bring about welfare improvement and is more likely to be achievable by the domestic political process.

\section{$\underline{\text { Sensitivity analysis }}$}

We now examine the robustness of the basic results with respect to the choice of the parameter values. We first let the tariff level prior to the formation of the blocs be $10 \%$, closer to the average of the current OECD countries' tariff levels. The result is in Figure 2. Our intuition suggests that a lower initial trade barrier implies that trade blocs would lead to a smaller change in welfare. Apart from this, the qualitative features remain the same as Figure 1. To ensure member countries of the blocs trade as much with non-members as before, they now have to reduce their external barriers by about $46 \%$ (from a $10 \%$ tariff rate to $5.4 \%$ ). On the other hand, to ensure Pareto improvement, they are only required to reduce external barriers by about $12 \%$ (from a $10 \%$ tariff rate to $8.8 \%$ ).

We also vary the utility parameter, $\theta$. In the top panel of Figure 3 , we lower $\theta$ to 0.6 , which means that different goods are now less substitutable than in the benchmark case. Again, the degree of external liberalization required for a welfare improvement (13\%) is much smaller than the Kemp-Wan-McMillan criteria (about 45\%). In the lower panel of Figure 4, we raise 
$\Theta$ to 0.85 , making the goods highly substitutable. In this case, three continental blocs always improve world welfare even without any external liberalization. On the other hand, following the McMillan proposal, one would have to require member countries of the blocs to reduce their external barriers by $32 \%$ before they are allowed to implement their regional bloc agreements.

So far, we have set the transport cost among countries on the same continent, $\alpha$, at zero. In the real world, the weighted average of intra- and inter-continental transport and insurance costs is about $6 \%^{3}$. As a robustness check, we set $\alpha=3 \%$ in Figure 4 . In the top panel, we retain $b$ at $15 \%$; whereas in the lower panel, we lower $b$ to $10 \%$. In both cases, the basic results of the earlier figures carry through. A relatively large external liberalization (about $40 \%$ or more) is required to ensure that the level of trade between members of trading blocs and nonmembers does not fall after the formation of the blocs. Again, only modest liberalization (about $6 \%$ or less) is needed to ensure a welfare increase from the continental blocs.

The benchmark case assumes a world of three continents with two countries on each continent. To be more realistic, we also examine the case of three continents with fifteen countries on each continent. The result is graphed in Figure 5. In this case, the critical values of external liberalization go up both for the trade volume and the welfare criteria. Intuitively, as there are more countries outside each bloc now (30 as opposed to 4), there is a greater scope for trade blocs to divert trade. In the model, almost $90 \%$ external liberalization is required to make sure that trade between member countries and non-members will not fall. About 58\% external liberalization is needed to ensure welfare improvement.

3 The ratios of $c . i . f$. and f.o.b. values of the world trade were 1.066 in 1980 and 1.053 in 1989. Table 36 from Review of Maritime Transport 1990. UNCTAD, U.N..: New York, 1991. 


\section{Partial internal liberalization}

Up to now, whenever countries form a bloc, we have required them to eliminate completely barriers among member countries (i.e., setting $k=1$ ). This is required by GATT Article 24. There are two reasons to consider less-than-complete within-bloc liberalization. First, from a normative or welfare viewpoint, less-than-complete internal liberalization is often better than complete liberalization (Meade, 1955; Frankel, Stein and Wei, 1994). Second, many existing regional blocs in fact implement varying degrees of liberalization across sectors among the member countries. For example, the average effective level of liberalization within the European Community in 1990 is estimated to be around fifty to sixty percent (Frankel, Stein and Wei, 1994).

In Figure 6, we continue to consider a world of three continents with fifteen countries on each. This time, we set within-bloc liberalization at $50 \%$. For example, starting with a tariff level of $30 \%$, member countries of a bloc lower their tariffs against each other to $15 \%$. To ensure that trade volume with non-member countries does not fall, the degree of external liberalization relative to that internally must be $85 \%$ or higher. That is, member countries have to reduce their external tariff rate from $30 \%$ to $17 \%(=30 \% *(1-0.5 * 0.85))$ or lower.

On the other hand, to make sure that the blocs represent a welfare improvement from the status quo, the relative degree of external liberalization is less than $25 \%$. That is, member countries only need to reduce their external tariff rate from $30 \%$ to $26 \%(=30 \% *(1-0.5 * 0.25))$.

To summarize, external liberalization is needed to ensure that trade volume with nonmembers does not fall (the McMillan criterion) and that world welfare does not fall. If many parts of the world contemplate forming regional trade blocs simultaneously, a relatively dramatic 
degree of external liberalization is required to ensure trade volume with non-members be kept the same as before. On the other hand, a relatively modest degree of external liberalization is needed for continental trade blocs to be welfare improving.

\section{Empirical evidence}

In this section, we examine empirically whether the current pattern of regionalization of trade conforms to the notion of "open regionalism."

\section{Empirical norm of trade volume}

In order to make inferences on whether trade between countries inside and outside trade blocs is high or low, or has gone up or down, we have to control economic, geographic and cultural factors. A useful framework for this purpose is the gravity model that establishes a "norm" for bilateral trade volume as a function of these "natural" factors. A dummy variable can then be added to represent the case when both countries in a given pair belong to the same regional grouping. One can check how the level of trade and time trend in, for example, East Asia compare with those in other groupings.

The key elements of the gravity model $^{4}$ have been justified by an imperfect competition/differentiated product framework (Anderson, 1979; and Helpman and Krugman, 1985). Indeed, Helpman (1987) asserted that the empirical success of the gravity model is an evidence supporting the relevance of the imperfect competition model. In such a framework,

4 In particular, the proposition that the bilateral trade volume is proportional to the two countries' sizes. 
adding transport cost/distance is relatively straightforward (Stein and Frankel, 1994; and Frankel, Stein and Wei, 1994). Overturning a conventional wisdom, Deardorff (1995) recently demonstrated that the gravity model is quite compatible with the traditional Ricardian or Heckscher-Ohlin models as well.

We employ a panel regression technique to examine this issue. Our data set covers 63 countries (or 1,953 country pairs) for the 1970-1992 period (1970, 1980, 1990 and 1992). The source is the United Nation trade matrix ${ }^{5}$ for 1970 and 1980, and the International Monetary Fund's Direction of Trade Statistics for 1990 and 1992.

The dependent variable in our gravity estimation is the bilateral volume of total trade (exports plus imports), in logarithmic form.

One would expect the two most important factors in explaining bilateral trade flows to be the geographical distance between the two countries, and their economic size. These factors are the essence of the gravity model (and indeed are the presumed source of the name, by analogy to the formula for gravitational attraction between two masses).

A large part of the apparent bias toward intra-regional trade is certainly due to simple geographical proximity. Despite the obvious importance of distance and transportation costs in determining the volume of trade, empirical studies surprisingly often neglect to measure this factor. Our measure is the log of distance between the two major cities (usually the capital) of the respective countries. We also add a dummy "Adjacent" variable to indicate when two countries share a common land border.

Entering GNPs in product form is empirically well-established in bilateral trade

5 The 63 countries constitute the universe of all countries in the UN Trade Matrix minus a few countries in the former soviet Bloc. 
regressions and can be justified by theories as mentioned above. There are reasons to believe that GNP per capita also has a positive effect, for a given size: as countries become more developed, they tend to specialize more and to trade more; furthermore, more developed countries have better ports and communication systems that facilitate goods trade.

A common language can facilitate trade partly because it directly reduces transaction (translation) costs and partly because it enhances exporters' and importers' understanding of each other's culture and legal system, which indirectly promotes trade. To capture this effect, we also include a dummy that takes the value of one if the country pair in question share a common language or has a previous colonial connection. We consider nine languages: English, French, German, Spanish, Portuguese, Dutch, Arabic, Chinese and Japanese.

A representative specification is:

$$
\begin{aligned}
& \log \left(T_{t f}\right)=\alpha+\beta_{1} \log \left(G N P_{1} G N P_{f}\right)+\beta_{2} \log \left(G N P / p \circ p_{1} G N P / p \circ p_{f}\right) \\
& +\beta_{3} \log (D I S T A N C E)+\beta_{4}(A D J A C E N T)+\beta_{5}(\text { LANGUAGE }) . \\
& +\gamma_{1}\left(\text { W. Europe } e_{i j}\right)+\gamma_{2}\left(\text { W. Hemisphere } e_{i j}\right)+\gamma_{3}\left(E \cdot A S I A_{i j}\right)+u_{i j} .
\end{aligned}
$$

The last five explanatory factors are dummy variables. W.Europe (Western Europe), W.Hemisphere (Western Hemisphere), and E.ASIA (East Asia) are examples of the dummy variables we use when testing the effects of membership in a common regional grouping.

We employ a quasi-panel regression technique that allows for year-specific intercepts. Unlike usual panel regressions, we do not include country pair dummies since that would undermine our effort in detecting possible intra-regional biases (and the effects of some of the gravity variables that do not change over time). 
In line with the regressions in Frankel, Stein and Wei(1994), we focus on four implicit regional blocs: Western Europe, the Western Hemisphere, East Asia and the APEC group. Define W.Eur1 as a dummy taking the value of one when the country pair involves at least one Western European country and zero otherwise. Define W.Eur2 as a dummy if both countries are in Western Europe. In a gravity regression with these dummies, one may interpret the coefficient on W.Eur1 as the extent of abnormal trade between Western European countries and a country outside the region relative to a random pair of countries in the world. A negative coefficient implies that trade between a member of the bloc and a non-member is smaller, on average, than two otherwise identically-situated countries. This is indicative of possible trade diversion. On the other hand, a positive coefficient implies that trade between Western European countries and countries outside the region is higher than what one would have expected from their economic, geographic and linguistic positions. Thus, a positive coefficient is taken as possible evidence of an open trade bloc. It is important to note that, even a zero coefficient could be consistent with welfare-improving trade blocs, because trade volume criterion is a sufficient but not necessary condition for welfare improvment.

The coefficient on W.Eur2 dummy represents any extra amount of trade between two European countries relative to their trade with countries outside the region. In other words, even if trade between France and England is the same as that between two identical countries outside Europe, the coefficient on W.Eur2 could still be positive if England, France and other Western European countries trade less, on average, with countries outside the region. We define dummies for the other regions in a similar way.

The results are presented in Table 1 . We first note that the basic gravity variables have 
sensible coefficients. The GNP variable has a positive and statistically significant coefficient: A one percent increase in economic size is associated with about 0.8 percent increase in trade. Per capita GNP is also positively related to trade. As predicted, distance has a negative coefficient: A one percent increase in distance is associated with a smaller trade by 0.6 percent. Two countries sharing a common language or colonial past also tend to trade more (by $40 \%$ ).

Our central focus is on regional pattern of trade volumes. For comparison, Column 1 reports a regression that includes only the dummies for within-bloc biases. The results with this more up-to-date data set are broadly similar to those in our earlier papers: There is evidence of intra-regional bias in each of the four potential blocs in question. During the period 1970-1992, two Western European countries traded $17 \%$ more than two otherwise similar non-Western European countries. The Western Hemisphere showed a slightly higher intra-regional bias (about $40 \%$ of extra trade). East Asia showed a much higher bias: Two East Asian economies traded $145 \%$ [exp(.899)-1] more than two otherwise similar economies outside the region. The group that exhibited the highest inward bias is APEC with a coefficient of 1.15.

Our central interest is the evidence regarding the openness of these blocs to outside countries. In Column 2, we include the dummies that represent trade between members of a bloc and countries outside the bloc. As it turns out, during the period 1970-92, both the Western Europe and East Asia groups were "open" in the sense that their trade in general was higher than what one would have expected from their economic, geographic and cultural characteristics. A Western European country tended to trade $10 \%$ more with everyone than otherwise similar countries. Interestingly, East Asia was even more open than Europe even though it also had a very high intra-regional bias. An East Asian country traded 100\% [exp(.715)-1] more with a 
country outside the region than two random countries both outside East Asia. To be sure, these results do not mean that Western Europe and East Asia did not favor trade among themselves relative to trade with outsiders. What they mean is that, for both regions, the formation of (an implicit if not explicit) trade bloc has not led to a substantial amount of trade diversion from countries outside the regions. Indeed, the trade blocs in these regions appear to have promoted their openness in general, even though trade among themselves may have grown even larger.

In contrast, both the Western Hemisphere and the APEC group display signs of trade diversion away from countries outside the regions, towards those inside. Trade between a Western Hemisphere country and an outsider during the period 1970-1992 appeared to be lower by $8 \%$ than one would have expected based on their economic and geographic characteristics. The APEC group appears in the estimates to have a greater degree of trade diversion: trade between an APEC member and a non-member was lower by $24 \%$ than two random countries outside the region.

So far, we have looked at the period average of intra-regional bias and of openness for the four blocs over the entire two-decade period. It may be of interest to examine how these indicators change over time. To do this, we create a variable, "Trend," which is equal to the year of the observation minus 1970. We add interaction terms between this variable and regional bias and openness dummies. The coefficient on the interaction terms can be interpreted as an annual percentage change in the relevant indicator.

The results are reported in Table 2. Again, the first column only has the intra-regional bias dummies (and their interaction with "Trend"). Although all four groups exhibit inward trade biases (as we have seen from Table 1), there is quite a bit of variation in terms of their 
dynamics. For Western Europe, the bias started high (24\%) in 1970 and more or less remains that way to the end. For East Asian bias, it started very high $[290 \%=\exp (1.36)-1]$ and declined steadily over the next 23 years at the rate of $3.2 \%$ per annum. The intra-APEC bias started high $[130 \%=\exp (.84)-1]$ and continued to grow over the period at the rate of $2.1 \%$ per annum. In contrast, two Western Hemisphere countries at the beginning of the 1970 s actually traded $27 \%$ less than two random countries outside the region. Over time, the intra-Hemisphere trade increased at a fast rate of $4.5 \%$ a year so that a strong intra-regional bias can be easily detected over the entire 23-year period.

Column 2 reports trend changes in the degree of openness of various trade groups. At the beginning of the sample, both Western Hemisphere countries and members of the current APEC group traded less with countries outside their regions than would be indicated by the predictions of the gravity model, although the differences are not statistically significant. Somewhat surprisingly, over the period 1970-92, the point estimates of the degree of trade diversion appear to have increased for both groups. The change is statistically significant for the APEC group (a reduction in trade at the rate of $1.6 \%$ per annum).

Western European countries were quite open at the beginning of the sample. Their trade with countries outside the region in 1970 was $30 \%$ more than random non-Western European countries. Over time, however, their trade with countries outside the region actually fell at the rate of $1.6 \%$ per annum. So during these twenty three years, these estimates show a steady diversion of trade away from countries outside Western Europe, towards countries inside. Because of their high degree of openness in 1970, the average trade between Western Europe and outside countries over the entire sample was still higher than the prediction of our gravity 
model. However, at the end of the sample, the trade between Western Europe and countries outside the region was below what one would have expected based on economic, geographic and cultural characteristics.

East Asia is unique relative to other groups. It was very open at the beginning of the sample: the trade between an East Asian economy and a country outside the region in 1970 was more than $36 \%$ higher than a random pair. The indicator of East Asian openness actually grew at the rate of $2.6 \%$ a year over the next two decades. Hence, to the extent that there may be an implicit trade bloc in East Asia, this bloc appears to have promoted trade creation and openness as opposed to trade diversion ${ }^{6}$. If all the regional trade groups, implicit as well as explicit blocs, were like East Asia, world welfare would likely be enhanced by continent-based trade regionalization.

\section{Concluding remarks}

The recent wave of trade regionalization has spread to almost all continents in the world. There are warnings that trade regionalization may decrease world welfare.

The notion of "open regionalism" and a proposal by McMillan to modify GATT Article XXIV based on the Kemp-Wan theorem aim to minimize the possibility of welfare-reducing trade blocs, while still preserving the opportunity for welfare-improving ones to emerge. To

6 We caution readers that our empirical strategy does not formally distinguish between two possibilities: 1) all East Asian economies liberalize unilaterally independent of the implicit bloc in the region, versus 2) they do so by a collective regional action, or by conscientiously following each other's example. 
satisfy the McMillan condition of not lowering trade volume with outside countries, member countries of trade blocs have to undertake dramatic trade liberalization against non-member countries. Such sweeping liberalization may be difficult to achieve, for political economy reasons. On the other hand, an open regionalism in which trade blocs undertake relatively modest external liberalization can usually produce Pareto improvement.

This paper concentrates on an efficiency analysis of external liberalization, while abstracting away from the dynamics and the concrete mechanism through which external liberalization (or its absence) takes place.

In the bilateral trade data during $1970-92$, there are regions that, while exhibiting an inward trade bias, nevertheless are consistent with the notion of open regionalism. In particular, if all continents pursue the same trade pattern as East Asia, a continent-based trade regionalization can be Pareto-improving for world welfare. 


\section{References}

Anderson, James. 1979. "A Theoretical Foundation for the Gravity Equation," American Economic Review 69, 1 (March): 106-116.

Anderson, Kym, and Hege Norheim. 1993. "History, Geography and Regional Economic Integration," in Regionalism and the Global Trading System, K.Anderson and R.Blackhurst, eds., London: Harvester Wheatsheaf.

Balassa, Bela. 1987. "Economic Integration" in The New Palgrave Dictionary of Economics, MacMillan Press Reference Books, London: 43-47.

Baldwin, Richard, 1989, "Economic Growth Effects of 1992," Economic Policy, October, pp.248-281.

Baldwin, Richard, 1992, "Measurable Dynamic Gains from Trade," Journal of Political Economy, Vol.100, No.1, p 162-174.

Bergsten, C. Fred, "Apec and World Trade," Foreign Affairs, May/June 1994, p24.

Bergstrand, Jeffrey. 1989. "The Generalized Gravity Equation, Monopolistic Competition, and the Factor-Proportions Theory in International Trade," Review of Economics and Statistics 71, no.1, Feb.: 143-152.

Bhagwati, Jagdish. 1971. "Trade-Diverting Customs Unions and Welfare Improvement: A Clarification," Economic Journal, 63.

Bhagwati, Jagdish. 1993, "Regionalism and Multilateralism: An Overview," in J. de Melo and A. Panagariya, eds. New Dimensions in Regional Integration New York: Cambridge University Press.

Bhagwati, Jagdish, and T.N. Srinivasan. 1983. Lectures on International Trade, Cambridge: MIT Press, Chapter 27.

Deardorff, Alan. 1984. "Testing Trade Theories and Predicting Trade Flows," in R.Jones 
and P.Kenen, eds., Handbook of International Economics vol. I. Amsterdam, Elsevier Science Publishers. Ch. 10: 467-517.

Deardorff, Alan, 1995, "Determinants of Bilateral Trade," paper prepared for the NBER Conference on Regionalism in Woodstock, Vermont, October 20-21, 1995.

Deardorff, Alan, and Robert Stern. 1992. "Multilateral Trade Negotiations and Preferential Trading Arrangements," RFIE Discussion Paper No. 307, University of Michigan, July. Forthcoming in Deardorff and Stern, eds., Analytical and Negotiating Issues in the Global Trading System, Ann Arbor: University of Michigan Press.

de Melo, J., A. Panagariya, and D.Rodrik. 1993. Regional Integration: An Analytical and Empirical Overview, in J. de Melo and A. Panagariya, New Dimensions in Regional Integration (New York: Cambridge University Press).

Frankel, Jeffrey. 1993. "Is Japan Creating a Yen Bloc in East Asia and the Pacific?" in Regionalism and Rivalry: Japan and the U.S. in Pacific Asia, edited by Jeffrey Frankel and Miles Kahler, Chicago: University of Chicago Press.

Frankel, Jeffrey, Ernesto Stein, and Shang-Jin Wei. 1994. "Trading Blocs: The Natural, the Unnatural, and the Super-Natural." Full version, CIDER Working Paper C94-034, U.C. Berkeley, April. Abridged version, Journal of Development Economics, June 1995.

Frankel, Jeffrey, Ernesto Stein, and Shang-Jin Wei. 1994. "Continental Trading Blocs: Are They Natural or Super-Natural?" NBER WP Revised, May, 1995.

Frankel, Jeffrey and Shang-Jin Wei, 1993, "Trade Blocs and Currency Blocs." NBER Working Paper 4335, Cambridge, MA.

Frankel, Jeffrey, and Shang-Jin Wei. 1994. "Yen Bloc or Dollar Bloc: Exchange Rate Policies of the East Asian Economies", in Macroeconomic Linkages: Savings, Exchange Rates and Capital Flows, Takatoshi Ito and Anne Krueger, editors, Chicago: University of Chicago Press, pages 295-329. 
Frankel, Jeffrey and Shang-Jin Wei, 1995, "Regionalization of world trade and currencies: Economics and Politics." Paper prepared for the NBER Conference on New Regionalism, to be held in Woodstock, Vermont, October 20-21, 1995.

Haveman, Jon David, 1992, "On the Consequences of Recent Changes in the Global Trading Environment." Ph.D dissertation. University of Michigan.

Helpman, Elhanan. 1987. "Imperfect Competition and International Trade: Evidence from Fourteen Industrial Countries," Journal of the Japanese and International Economies 1: 62-81.

Helpman, Elhanan and Paul Krugman. 1985. Market Structure and Foreign Trade, Cambridge, MA, MIT Press.

Kemp, M.C. and Henry Y. Wan, 1976, "An Elementary Proposition Concerning the Formation of Customs Union," Journal of International Economics 6: 95-97.

Krueger, Anne O., 1995, "Free Trade Agreements versus Customs Unions." NBER Working Paper No. 5084. April.

Krugman, Paul. 1980. "Scale Economies, Product Differentiation, and the Pattern of Trade," American Economic Review 70, 950-959.

Krugman, Paul. 1991a. "Is Bilateralism Bad?" in E.Helpman and A.Razin, eds., International Trade and Trade Policy. Cambridge, MA, MIT Press.

Krugman, Paul. 1991b. "The Move Toward Free Trade Zones," in Policy Implications of Trade and Currency Zones, A Symposium Sponsored by the Federal Reserve Bank of Kansas City, Jackson Hole, Wyoming, (August): 7-42.

Lawrence, Robert, 1992, "Regionalism and the Achievement of Deeper Global Integration, " Harvard University.

Linneman, Hans. 1966. An Econometric Study of International Trade Flows, NorthHolland, Amsterdam.

Levy, Philip. "A Political Economic Analysis of Free Trade Agreements." Center for 
Economic Policy Research Publication No. 347, Stanford University, January 1993.

McMillan, John, 1993, "Does regional integration foster open trade? Economic theory and GATT's Article XXIV," in Kym Anderson and Richard Blackhurst eds., Regional Integration and the Global Trading System.

Meade, James. 1955. The Theory of Customs Unions. Amsterdam: North-Holland.

Saxonhouse, Gary. 1993. "Pricing Strategies and Trading Blocks in East Asia," in Regionalism and Rivalry: Japan and the U.S. in Pacific Asia, edited by Jeffrey Frankel and Miles Kahler, University of Chicago Press: Chicago.

Srinivasan, T.N., 1993, "'Regionalism vs. Multilateralism: Analytical Notes' Comment," in J. de Melo and A. Panagariya, eds. New Dimensions in Regional Integration New York: Cambridge University Press.

Stein, Ernesto, and Jeffrey Frankel, 1993, "Transport Costs and the Welfare Effects of Free Trade Agreements," University of California, Berkeley.

Summers, Lawrence. 1991. "Regionalism and the World Trading System," in Policy Implications of Trade and Currency Zones, A Symposium Sponsored by the Federal Reserve Bank of Kansas City, Jackson Hole, Wyoming, (August): 295-302.

Tinbergen, Jan, 1962, Shaping the World Economy, The Twentieth Century Fund: New York.

Viner, Jacob, 1950, The Customs Union Issue, Carnegie Endowment for International Peace: New York.

Wei, Shang-Jin and Jeffrey Frankel, 1994, "Can Regional Blocs Be Building Blocks to Global Free Trade?" Unpublished. Harvard University and University of California at Berkeley. Wei, Shang-Jin and Jeffrey Frankel, 1995, "Open versus Closed Trade Blocs." prepared for the NBER Sixth East Asian Seminar on Economics in Seoul, Korea, June 16-18, 1995, organized by Takatoshi Ito and Anne $\mathrm{O}$. Kruger. 


\section{Appendix Fig 1}

Confirmation of the Krugman result without transport cost $\mathrm{t}=30 \%$, theta $=0.75$, a world of 60 countries

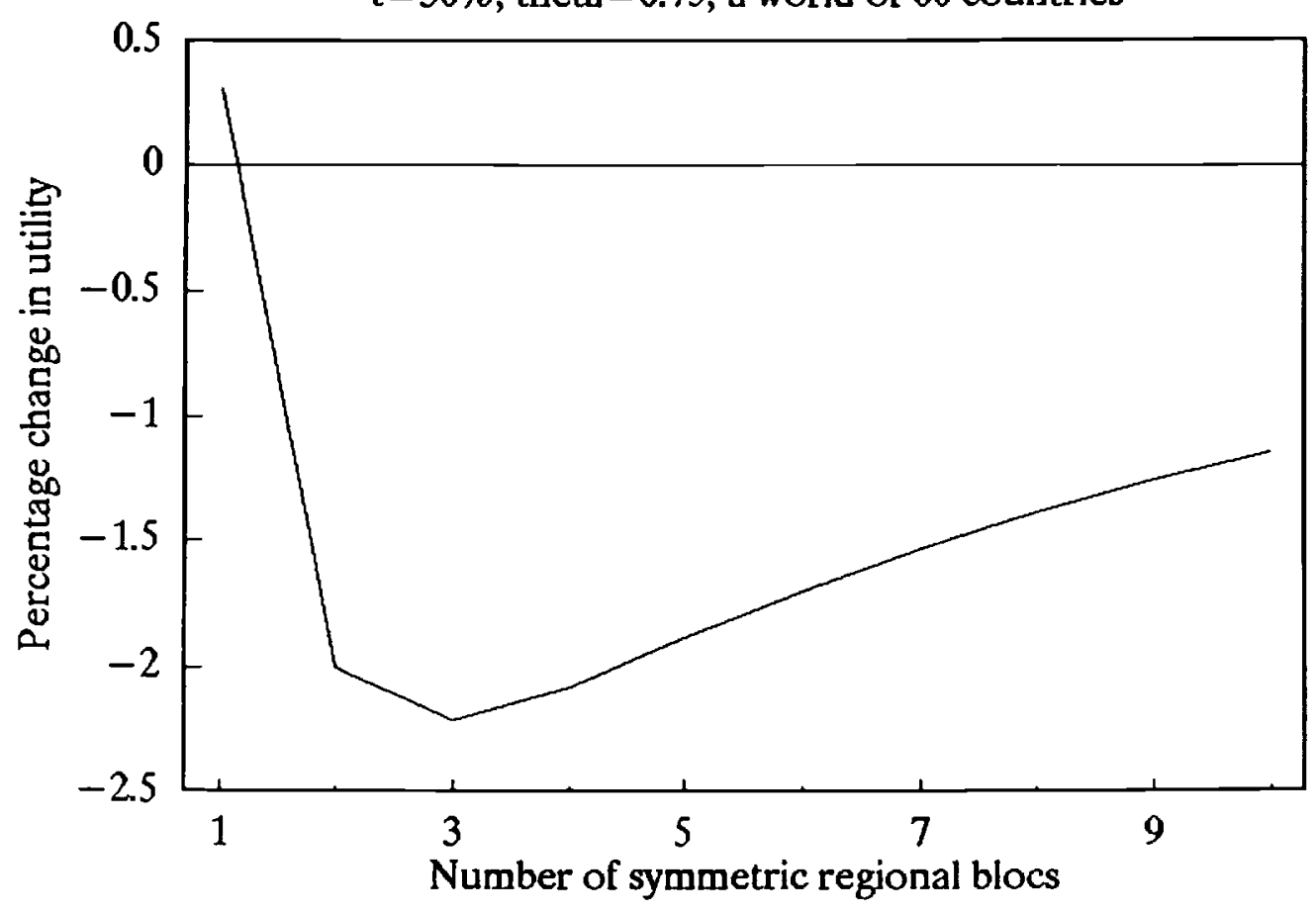

Appemeix Fig 2

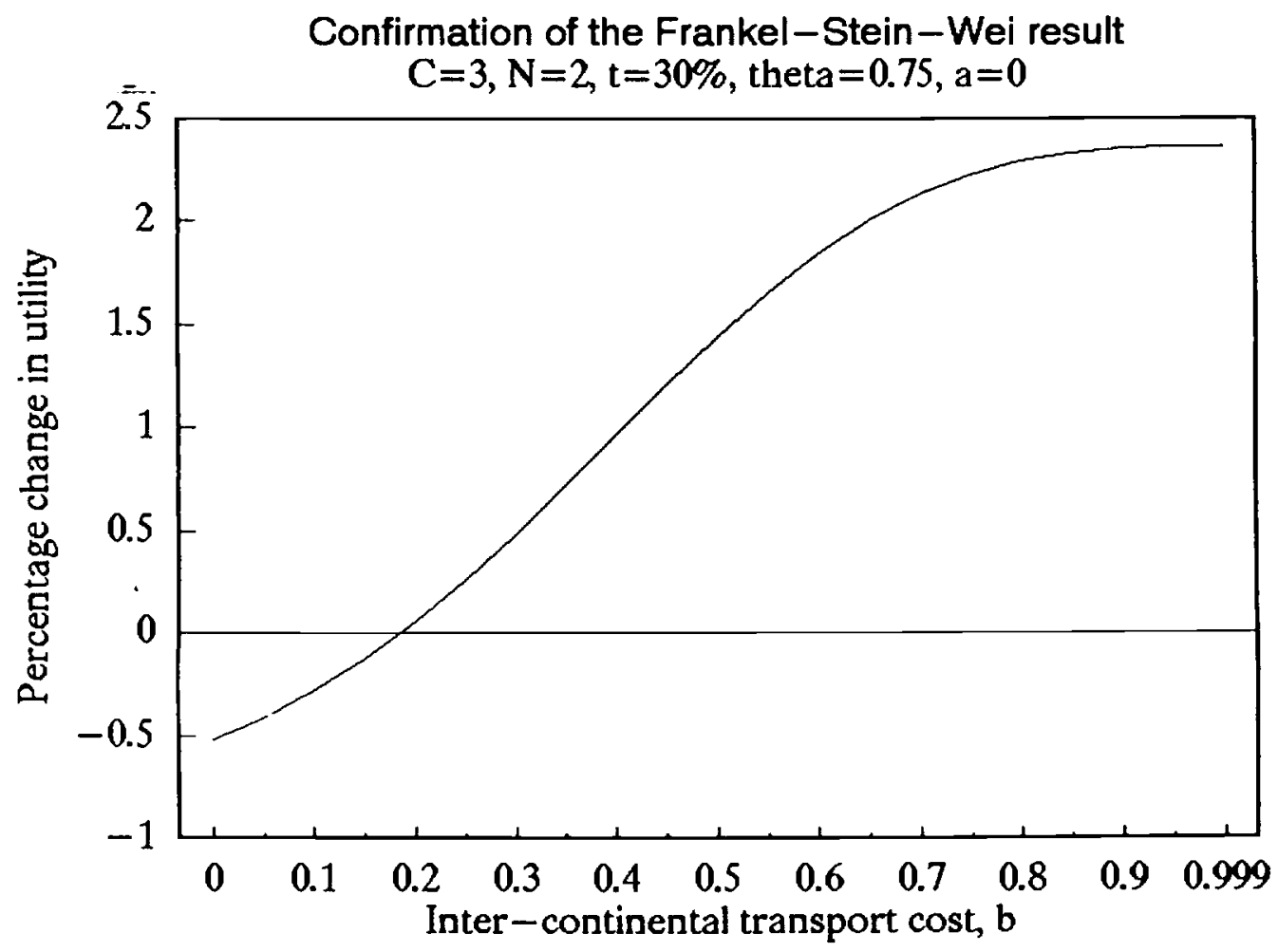




\section{Fig 1}

External Liberalization, Welfare and Trade Volume

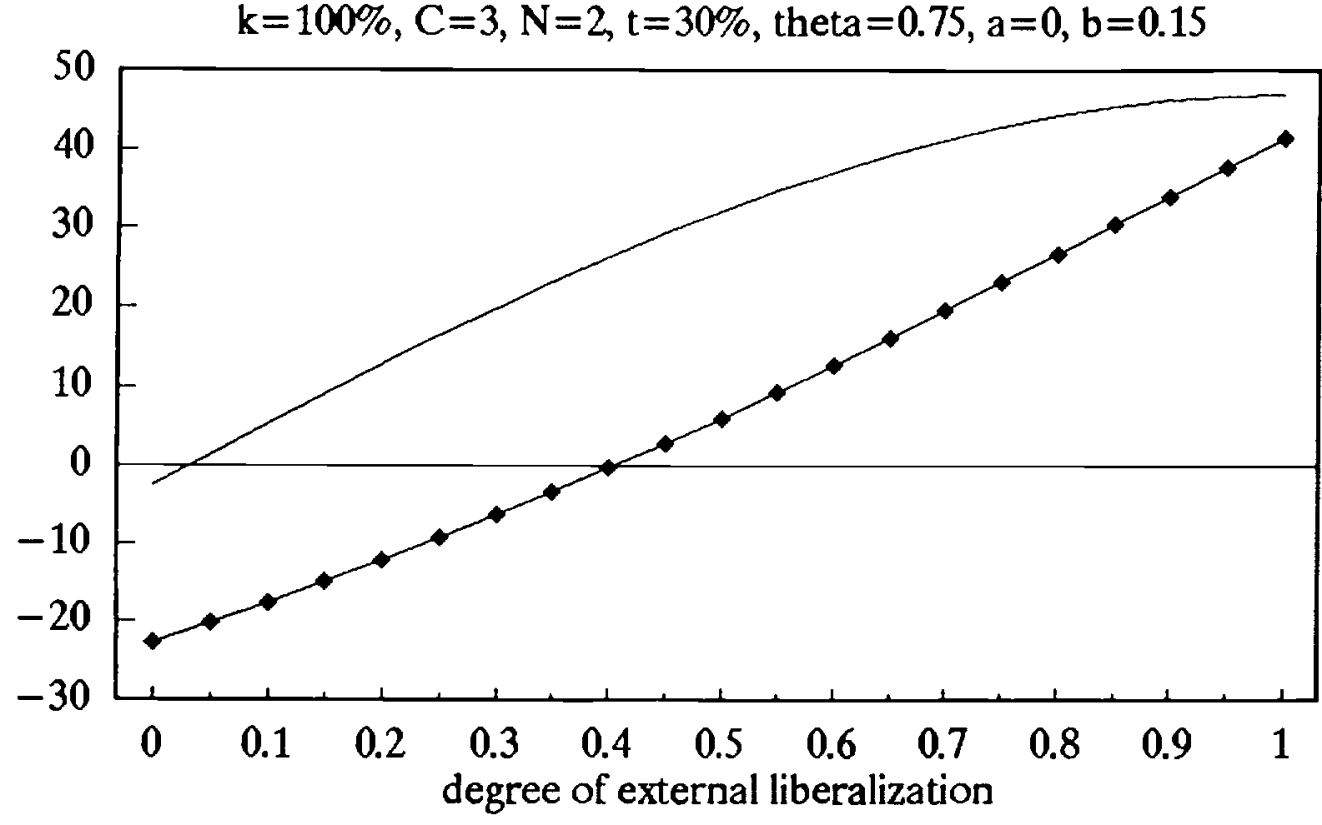

Percentage change in utility multiplied by 20

_- Percentage change in trade volume with non-members

Fig 2

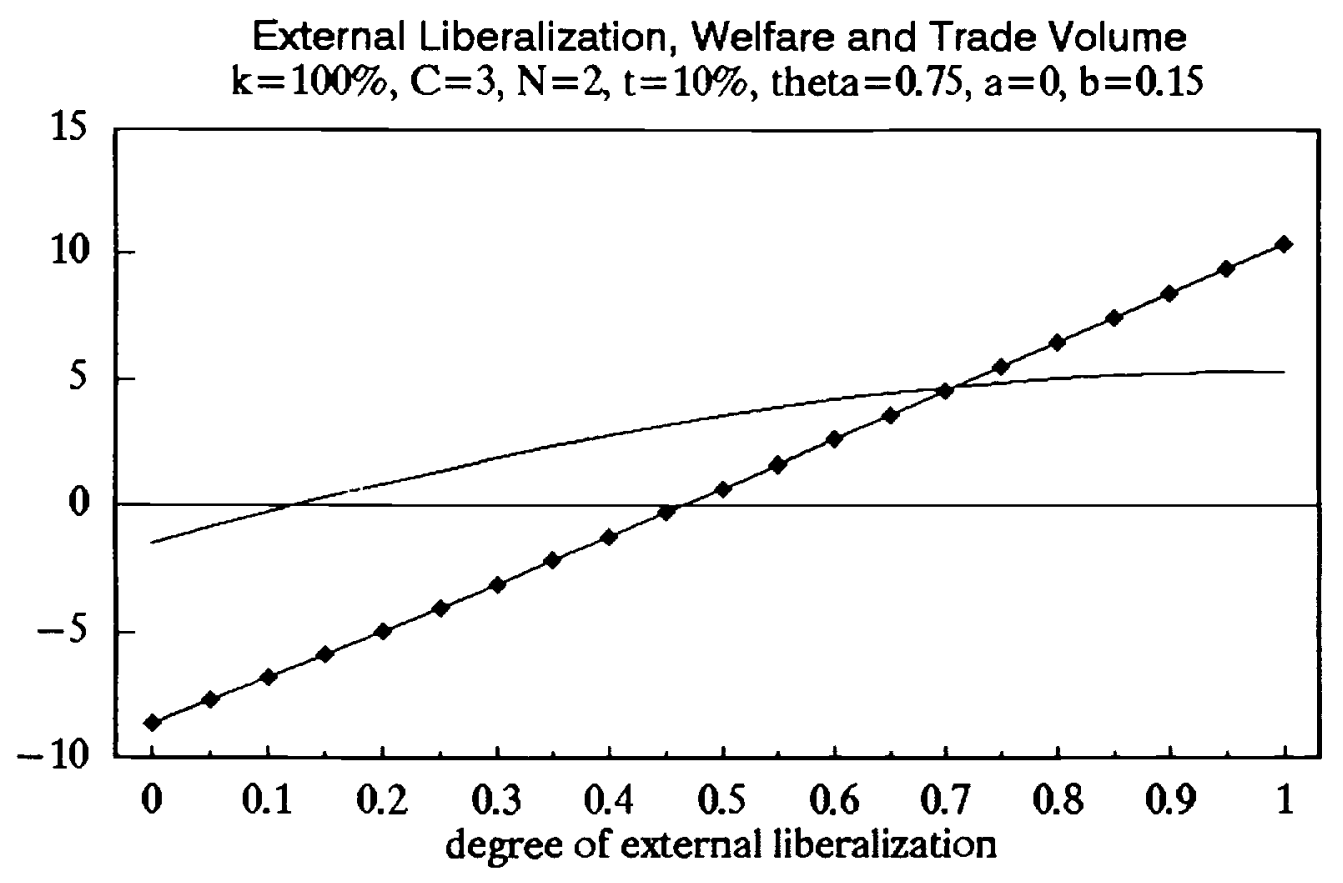

Percentage change in utility multiplied by 20

$\rightarrow$ Percentage change in trade volume with non-members 
Fig 3

External Liberalization, Welfare and Trade Volume

$\mathrm{k}=100 \%, \mathrm{C}=3, \mathrm{~N}=2, \mathrm{t}=30 \%$, theta $=0.6, \mathrm{a}=0, \mathrm{~b}=0.15$

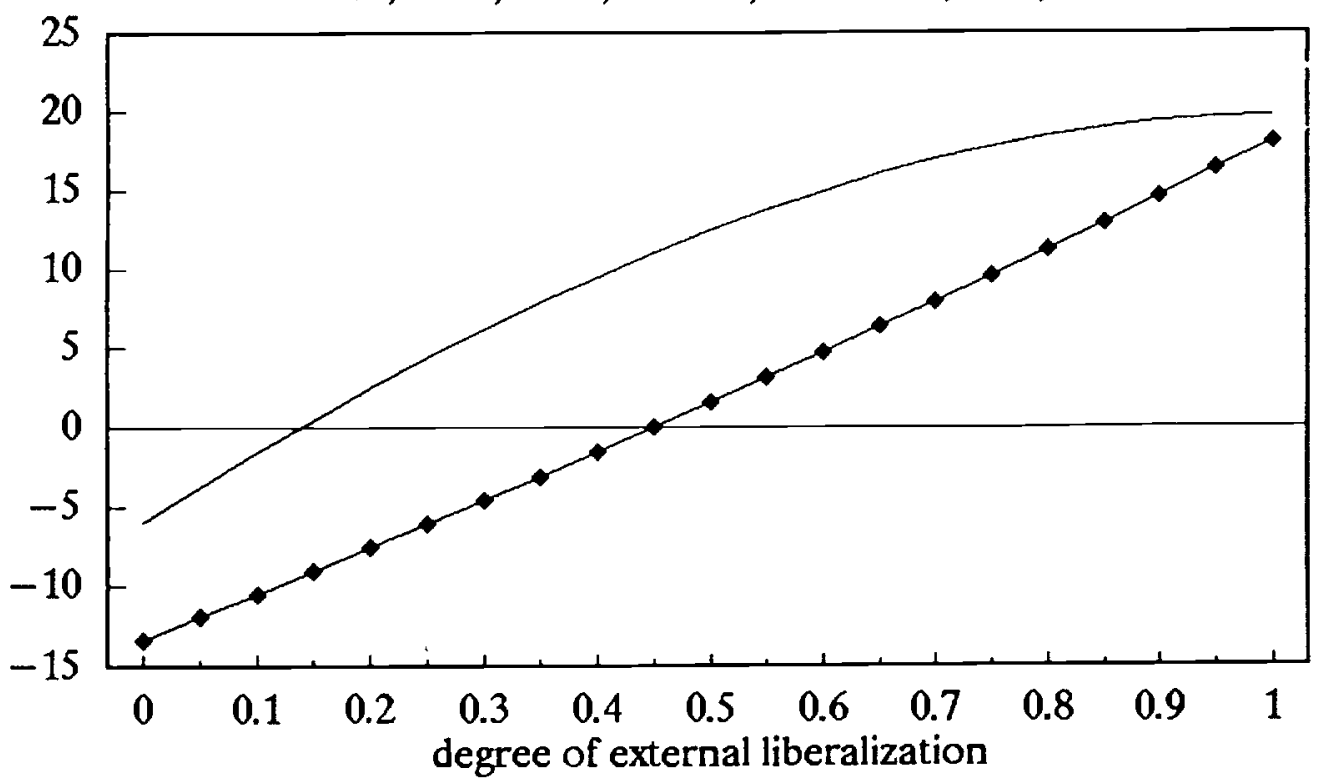

Percentage change in utility multiplied by 20

Percentage change in trade volume with non-members

External Liberalization, Welfare and Trade Volume

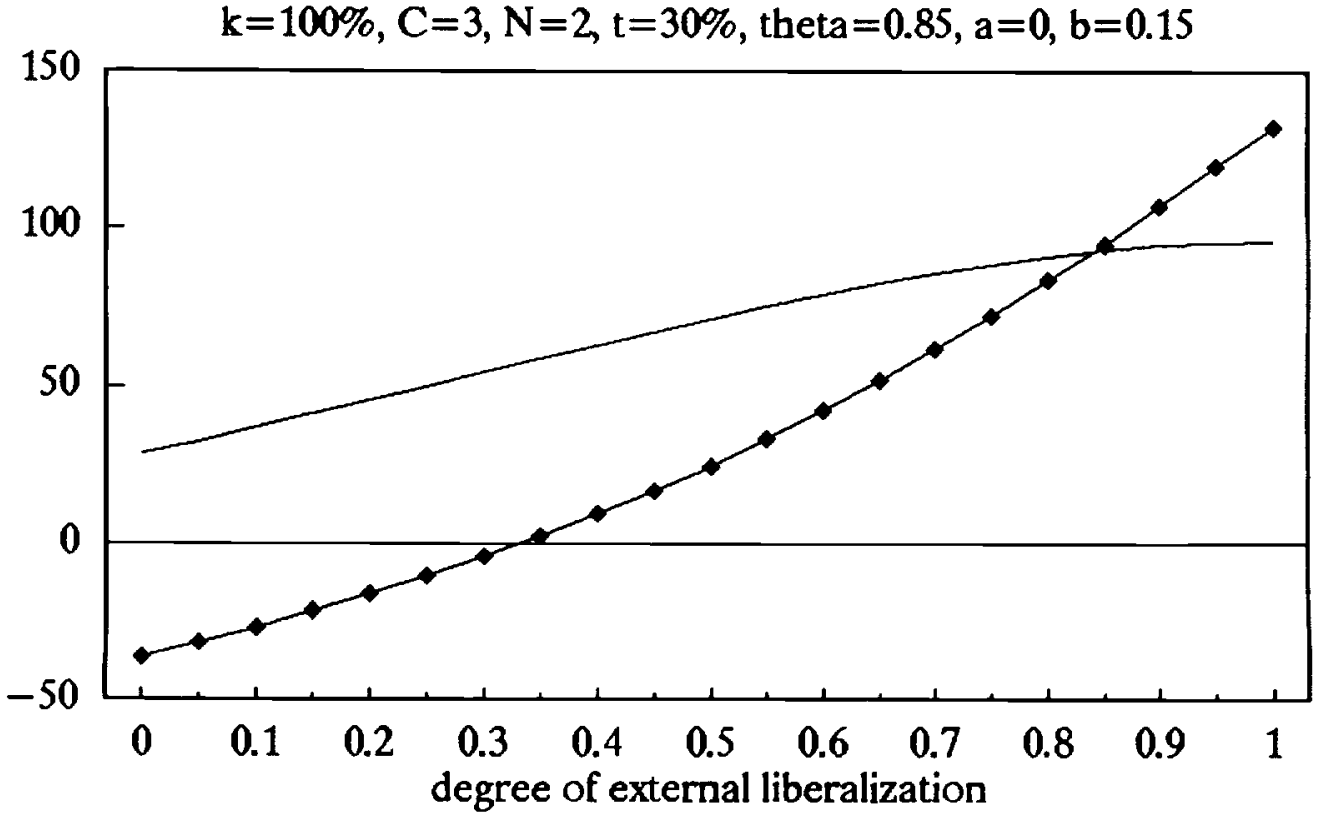

Percentage change in utility multiplied by 20

$\rightarrow$ Percentage change in trade volume with non-members 

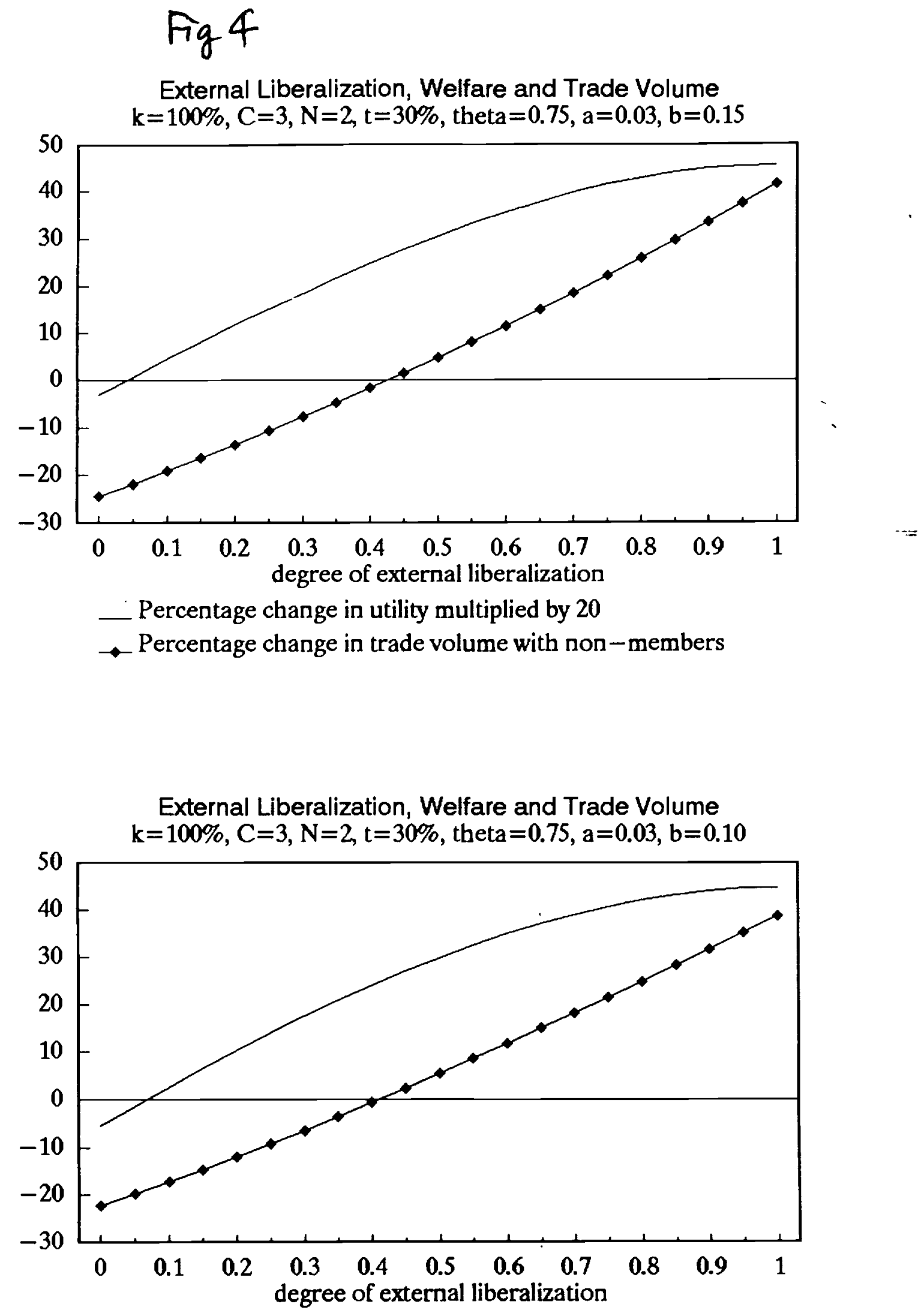

Percentage change in utility multiplied by 20

$\rightarrow$ Percentage change in trade volume with non-members 
Fig 5

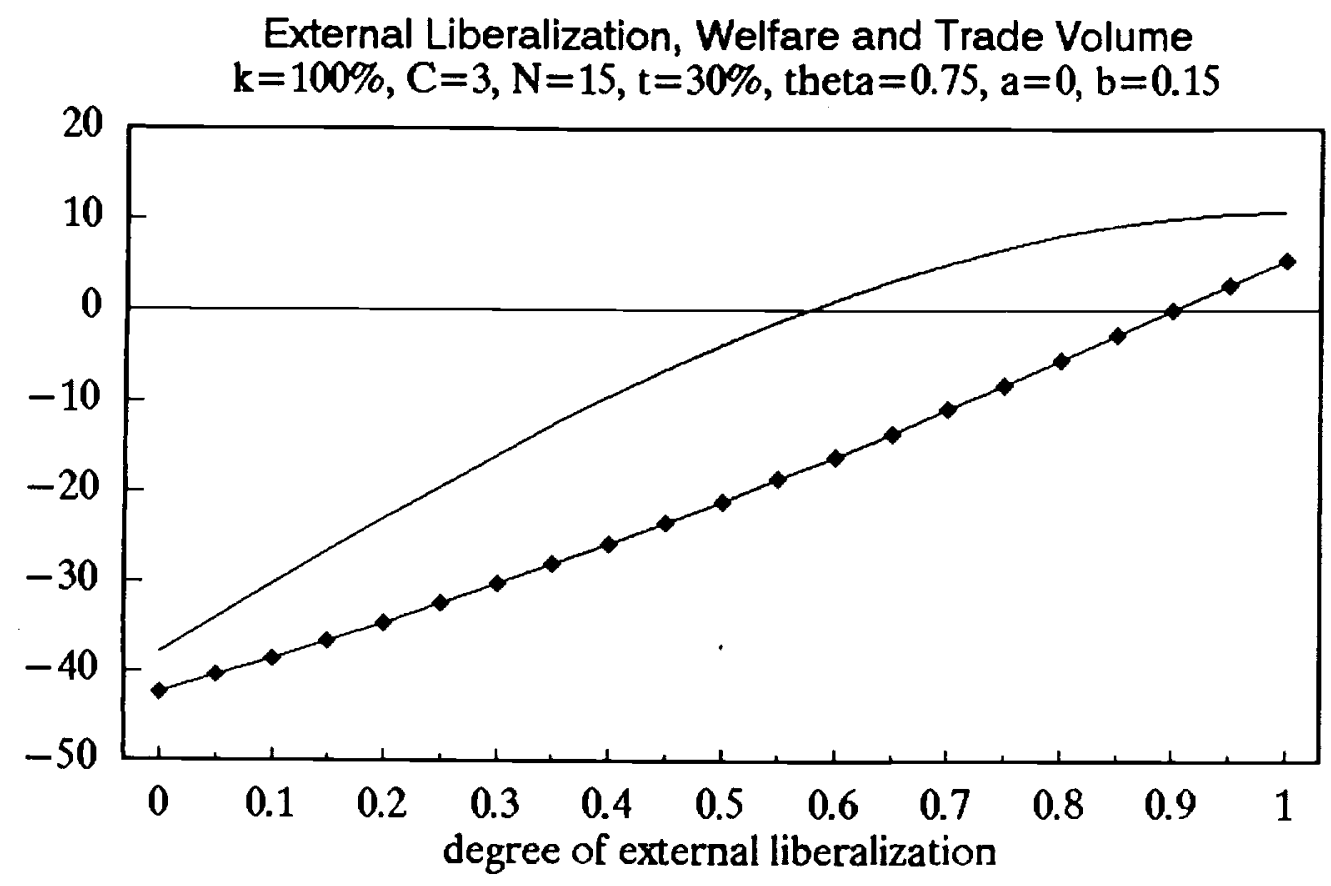

Percentage change in utility multiplied by 20

$\rightarrow$ _ Percentage change in trade volume with non-members

Fig 6

External Liberalization, Welfare and Trade Volume $\mathrm{k}=50 \%, \mathrm{C}=3, \mathrm{~N}=15, \mathrm{t}=30 \%$, thet $\mathrm{a}=0.75, \mathrm{a}=0, \mathrm{~b}=0.15$

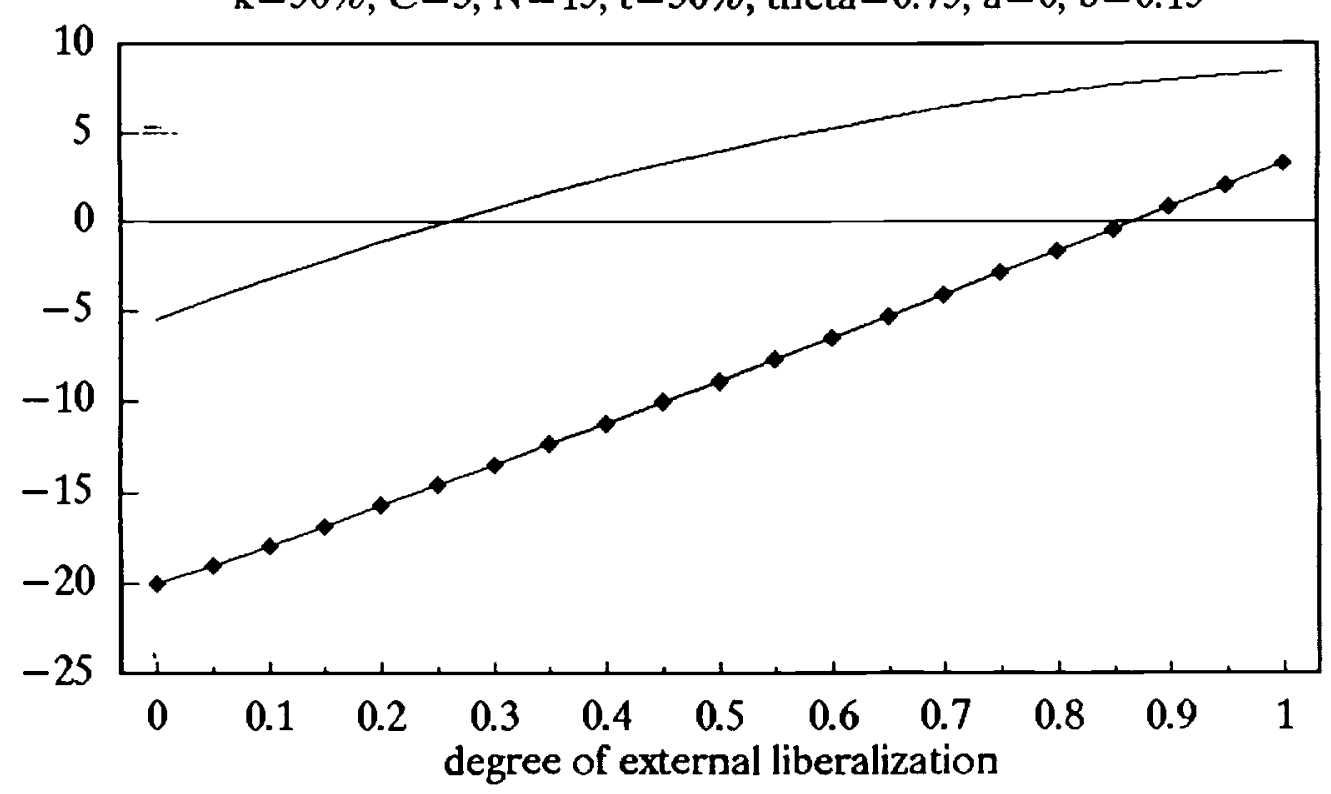

Percentage change in utility multiplied by 20

—-Percentage change in trade volume with non-members 
Table 1: Openness of Continental Trade Blocs Total Trade, 1972-1992

Dependent Variable: Trade $_{\mathrm{y}}$

\begin{tabular}{|c|c|c|}
\hline Intercept & $\begin{array}{c}-9.355^{* *} \\
(0.236) \\
\end{array}$ & $\begin{array}{c}-9.520^{*} * \\
(0.331)\end{array}$ \\
\hline 1980 Dummy & $\begin{array}{c}-1.030 * * \\
(0.049)\end{array}$ & $\begin{array}{c}-1.075^{* *} \\
(0.054)\end{array}$ \\
\hline 1990 Dummy & $\begin{array}{c}-1.323^{* *} \\
(0.055)\end{array}$ & $\begin{array}{c}-1.389^{* *} \\
(0.065)\end{array}$ \\
\hline 1992 Dummy & $\begin{array}{c}-5.278 * * \\
(0.153) \\
\end{array}$ & $\begin{array}{c}-5.332^{* *} \\
(0.169)\end{array}$ \\
\hline GNP & $\begin{array}{l}0.762^{* *} \\
(0.009)\end{array}$ & $\begin{array}{l}0.761^{* *} \\
(0.009)\end{array}$ \\
\hline $\begin{array}{c}\text { per-capita } \\
\text { GNP }\end{array}$ & $\begin{array}{l}0.194^{* *} \\
(0.011)\end{array}$ & $\begin{array}{l}0.214^{* *} \\
(0.013)\end{array}$ \\
\hline Distance & $\begin{array}{c}-0.586^{* *} \\
(0.021) \\
\end{array}$ & $\begin{array}{c}-0.611^{* *} \\
(0.028)\end{array}$ \\
\hline Adjacency & $\begin{array}{l}0.663^{* *} \\
(0.080)\end{array}$ & $\begin{array}{l}0.624^{* *} \\
(0.081)\end{array}$ \\
\hline Language & $\begin{array}{c}0.443^{* *} \\
(0.045)\end{array}$ & $\begin{array}{l}0.517 * * \\
(0.045)\end{array}$ \\
\hline W.Eur2 Blnc & $\begin{array}{l}0.167 * * \\
(0.053)\end{array}$ & $\begin{array}{l}0.120 * * \\
(0.053)\end{array}$ \\
\hline E.Asia2 Bloc & $\begin{array}{l}0.899 * * \\
(0.101)\end{array}$ & $\begin{array}{l}0.786^{* *} \\
(0.102)\end{array}$ \\
\hline Apec2 Bloc & $\begin{array}{l}1.147^{* *} \\
(0.063)\end{array}$ & $\begin{array}{l}0.937^{* *} \\
(0.071)\end{array}$ \\
\hline W.Hem.2 Bloc & $\begin{array}{l}0.355^{* *} \\
(0.070)\end{array}$ & $\begin{array}{l}0.637^{* *} \\
(0.079)\end{array}$ \\
\hline W.Eur1 Bloc & & $\begin{array}{l}0.101^{*} \\
(0.048)\end{array}$ \\
\hline E.Asial Bloc & & $\begin{array}{l}0.715^{* *} \\
(0.056)\end{array}$ \\
\hline Apec1 Bloc & & $\begin{array}{c}-0.276^{* *} \\
(0.059)\end{array}$ \\
\hline W.Hem.1 Bloc & & $\begin{array}{l}-0.082 \# \\
(0.044) \\
\end{array}$ \\
\hline \#Obs. & 6102 & 6102 \\
\hline$\Lambda$ dj. $R^{2}$ & 0.924 & 0.927 \\
\hline Std. Err. of Reg. & i.137 & 1.114 \\
\hline
\end{tabular}

Notes: 1. ** * \# denotes significant a! the $99 \%, 95 \%$, and $90 \%$ levels respectively

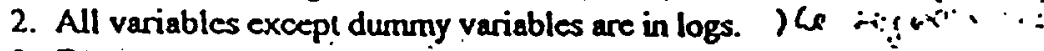

3. Data covers years 1970, 1980, 1990, and 1992.

4. Region I takes the value of one if the pair ineludes a country in the region. 
Dependent Variable: Trade $_{\mathfrak{l j}}$

\begin{tabular}{|c|c|c|c|c|}
\hline Intercept & $\begin{array}{c}-9.410^{* *} \\
(0.236)\end{array}$ & & $\begin{array}{c}-9.806^{* *} \\
(0.343)\end{array}$ & \\
\hline 1980 Durumy & $\begin{array}{c}-1.062^{* *} \\
(0.050)\end{array}$ & & $\begin{array}{c}-1.006^{*} \\
(0.068)\end{array}$ & \\
\hline 1990 Dummy & $\begin{array}{c}-1.378^{* *} \\
(0.058)\end{array}$ & & $\begin{array}{c}-1.242^{* *} \\
(0.107)\end{array}$ & \\
\hline 1992 Dummy & $\begin{array}{c}-5.358 * * \\
(0.154) \\
\end{array}$ & & $\begin{array}{c}-5.181^{* *} \\
(0.188) \\
\end{array}$ & \\
\hline GNP & $\begin{array}{l}0.763^{* *} \\
(0.009) \\
\end{array}$ & & $\begin{array}{l}0.762^{* *} \\
(0.009)\end{array}$ & \\
\hline $\begin{array}{c}\text { per-capita } \\
\text { GNP } \\
\end{array}$ & $\begin{array}{l}0.198 * * \\
(0.011)\end{array}$ & & $\begin{array}{l}0.222^{* *} \\
(0.013)\end{array}$ & \\
\hline Distance & $\begin{array}{c}-0.585^{* *} \\
(0.021) \\
\end{array}$ & & $\begin{array}{c}-0.605^{* *} \\
(0.028)\end{array}$ & $=$ \\
\hline Adjacency & $\begin{array}{l}0.667^{* *} \\
(0.078)\end{array}$ & & $\begin{array}{l}0.633^{* *} \\
(0.079)\end{array}$ & \\
\hline Language & $\begin{array}{l}0.445^{* *} \\
(0.045)\end{array}$ & & $\begin{array}{l}0.519^{* *} \\
(0.044)\end{array}$ & \\
\hline W.Eur2 Bloc & $\begin{array}{l}0.236^{* *} \\
(0.072)\end{array}$ & $\begin{array}{c}-0.006 \\
(0.004)\end{array}$ & $\begin{array}{c}0.117 \\
(0.078) \\
\end{array}$ & $\begin{array}{c}-0.001 \\
(0.004)\end{array}$ \\
\hline E.Asia2 Bloc & $\begin{array}{l}1.360^{* *} \\
(0.226) \\
\end{array}$ & $\begin{array}{l}-0.032 \\
(0.013)\end{array}$ & $\begin{array}{l}1.360^{* *} \\
(0.226)\end{array}$ & $\begin{array}{r}-0.040 \\
(0.013) \\
\end{array}$ \\
\hline Apec2 Bloc & $\begin{array}{l}0.841^{* *} \\
(0.134)\end{array}$ & $\begin{array}{l}0.021^{*} \\
(0.008)\end{array}$ & $\begin{array}{l}0.824^{* *} \\
(0.146)\end{array}$ & $\begin{array}{c}0.006 \\
(0.008)\end{array}$ \\
\hline W.Hem.2 Bloc & $\begin{array}{l}-0.237^{*} \\
(0.099) \\
\end{array}$ & $\begin{array}{l}0.045^{* *} \\
(0.007)\end{array}$ & $\begin{array}{c}0.021 \\
(0.116) \\
\end{array}$ & $\begin{array}{l}0.047^{* *} \\
(0.008)\end{array}$ \\
\hline W.Eur1 Bloc & & & $\begin{array}{l}0.303^{* *} \\
(0.075)\end{array}$ & $\begin{array}{l}-0.016^{k *} \\
(0.004)\end{array}$ \\
\hline E.Asial Bloc & & & $\begin{array}{l}0.363 * * \\
(0.106)\end{array}$ & $\begin{array}{l}0.026^{* *} \\
(0.006)\end{array}$ \\
\hline Apec1 Bloc & & & $\begin{array}{c}-0.079 \\
(0.089) \\
\end{array}$ & $\begin{array}{c}-0.016^{* *} \\
(0.005)\end{array}$ \\
\hline W.Hem.1 Bloc & & & $\begin{array}{r}-0.014 \\
(0.072) \\
\end{array}$ & $\begin{array}{c}-0.006 \\
(0.004) \\
\end{array}$ \\
\hline \# Obs. & & 6102 & & 6102 \\
\hline Adj. $R^{2}$ & & 0.924 & & 0.928 \\
\hline Std. Err. of Reg. & & 1.133 & & 1.107 \\
\hline
\end{tabular}

Notes 1.**. *. It denotes significant at the $99 \%$, $95 \%$, and $90 \%$ levels respoctivel::

2. All variables except durnmy variables are in logs.

3. Data covers years 1970, 1980, 1990, and 1992.

4. Regionl takes the value of one if the pair includes a country in the region.

5. Columns 3 and 5 are coefficients (standard errors) for the interaction between the variables in column 1 und a trend (defined as: year - 1970). 